\title{
Genetic diversity within and between broodstocks of the white shrimp Litopenaeus vannamei (Boone, 1931) (Decapoda, Penaeidae) and its implication for the gene pool conservation
}

\author{
Freitas, PD. *, Calgaro, MR. and Galetti Jr., PM. \\ Departamento de Genética e Evolução, Universidade Federal de São Carlos - UFSCar, \\ Rodovia Washington Luiz, Km 235, CP 676, CEP 13565-905, São Carlos, SP, Brazil \\ *e-mail: patdf@iris.ufscar.br \\ Received March 21, 2006 - Accepted April 12, 2007 - Distributed December 1, 2007
}

(With 2 figures)

\begin{abstract}
Genetic variation within and between fifteen closed broodstock lines of the Pacific white shrimp Litopenaeus vannamei, reared at different hatcheries in the Brazilian coast, was assessed by RAPD analysis. Fifty two polymorphic loci were identified when a set of five decamer primers was used in PCR. The genetic diversity analysis within lines evidenced genetic variation loss probably related to bottleneck effects and inbreeding. In addition, the genetic divergence values between the different samples appear to reflect the initial founder composition of such stocks, in some cases, sharing a common origin, suggesting a putative importance of interbreeding for the establishment of genetic improvement programs for these broodstocks. The genetic variation monitoring appears to be helpful to the gene pool conservation of this aquaculture species, mainly if considered its exotic status in Brazil and the current impossibility of new introduction of wild individuals.
\end{abstract}

Keywords: aquaculture, gene pool conservation, genetic variation.

\section{Diversidade genética dentro e entre estoques reprodutores do camarão branco Litopenaeus vannamei (Boone, 1931) (Decapoda, Penaeidae) e sua implicação para a conservação do conjunto gênico}

\begin{abstract}
Resumo
A variação genética existente dentro e entre quinze linhagens fechadas de reprodutores do camarão branco Litopenaeus vannamei, mantidas em diferentes laboratórios de larvicultura na costa brasileira, foi estudada utilizando análises RAPD. Através de um conjunto de cinco iniciadores decâmeros em PCR, foram identificados 52 locos polimórficos. A análise da diversidade genética dentro de cada linhagem evidenciou perda da variação genética provavelmente devida a efeitos de bottleneck e endocruzamento. Em adição, os valores de divergência genética entre as diferentes linhagens parecem refletir a composição inicial de fundação desses estoques, em alguns casos, compartilhando uma origem comum, sugerindo uma importância potencial do exo-cruzamento para estabelecer programas de melhoramento genético baseado nessas linhagens reprodutoras. O monitoramento da variação genética será muito útil para a conservação do conjunto gênico desta espécie de aquacultura, especialmente se for considerado seu status exótico no Brasil e que atualmente é impossível a realização de novas introduções de indivíduos selvagens.
\end{abstract}

Palavras-chave: aquacultura, conservação do conjunto gênico, variação genética.

\section{Introduction}

A long-term shrimp farming in the Brazilian coast can depend of how well we manage our national broodstocks of Litopenaeus vannamei (Penaeidae), an exotic species from the American Pacific coast. In the past years, Brazilian farmers have quickly increased their shrimp production exclusively based on this shrimp profits and the country is currently placed among the major producers of captive shrimp in the Western hemisphere (Rocha et al., 2004). However, the lack of knowledge on the genetic structure of this shrimp could impair farm- ing activity since inbreeding and genetic drift effects can rapidly lead to problems such as disease susceptibility and reduced quality of breeders and post-larvae (Freitas et al., 2001; Freitas and Galetti, 2002).

In the earlier years of the L. vannamei farming in Brazil, the broodstocks were formed through the importation of wild animals from Panama, Ecuador, Mexico, and Costa Rica, and reared animals from Venezuela. However, in order to avoid the introduction of exotic pathogens, the importation of wild or reared animals is 
not allowed since 1998, and new broodstock lines have been founded in the different Brazilian hatcheries by using their own captive-born animals. The gene pool conservation of this exotic species seems to be a great challenge. Presently, there are several closed lines at these different hatcheries spread throughout the Brazilian coast. Each hatchery presents broodstocks with peculiar characteristics, related to their different origin and captive conditions.

It is well known that a population can present a unique gene combination and the genetic structure of a set of reproductively isolated populations can mutually diverge (Barker, 1994). Moreover, the genetic variation has been claimed to be the original source to the successful development of captive stocks and it is believed that genetic variability loss restrains the possibilities of improvement of these animals (Allendorf and Ryman, 1987; Barker, 1994). Thus, an extensive genetic characterization of the Brazilian shrimp closed lines can be helpful to the development of breeding programs.

In the present work, the genetic diversity within and between fifteen L. vannamei broodstocks owned by seven Brazilian hatcheries was assessed by using RAPD analysis, in order to provide an original genetic data base useful for further breeding programs and for the gene pool conservation of this exotic shrimp in Brazil.

\section{Material and Methods}

\subsection{Broodstocks, sample collection, and DNA extraction}

Specimens of fifteen L. vannamei closed broodstock lines owned by seven Brazilian hatchery industries located at the States of Bahia (Lusomar and Maricultura), Rio Grande do Norte (Aquatec and Emparn), Paraíba (Compar and Aquamaris), and Santa Catarina (Ufsc), were analyzed (Table 1). Pleopod samples from 252 individuals were fixed in $1 \mathrm{~mL}$ of $95 \%$ ethanol and stored at $-20{ }^{\circ} \mathrm{C}$. DNA extraction was performed using a phenol: chloroform: isoamylic alcohol mix (Sambrook et al., 1989).

\subsection{RAPD-PCR and electrophoresis analysis}

The Ready-To-Go ${ }^{\text {TM }}$ RAPD Analysis Beads Kit (GE Healthcare Life Sciences) was used following the

Table 1. Data on the different studied broodstocks. Generation time $(\mathrm{G})$, number of analyzed animals (N), and within Jaccard's genetic similarity $\left(\mathrm{S}_{\mathrm{J}}\right)$.

\begin{tabular}{|c|c|c|c|c|c|}
\hline Broodstock & Hatchery & G & $\begin{array}{c}\text { Origin } \\
\end{array}$ & $\mathbf{N}$ & $\mathbf{S}_{\mathrm{I}}$ \\
\hline Mar F7 & Maricultura & $\mathrm{F}_{7}$ & $\begin{array}{l}\text { Closed line founded with individuals imported from } \\
\text { Panama ( } 80 \%) \text {, Ecuador, Mexico, Costa Rica, and } \\
\text { Venezuela (20\%) }\end{array}$ & 26 & 0.692 \\
\hline Mar NHP & Maricultura & $\mathrm{F}_{7}$ & $\begin{array}{l}\text { Survived animals derived from Mar } \mathrm{F}_{7} \text { Stock } \\
\text { (Maricultura) after contact with NHP bacteria }\end{array}$ & 20 & 0.683 \\
\hline Luso F0 & Lusomar & F0 & $\begin{array}{l}\text { Founded with animals from SECOM and EDUARDO } \\
\text { LEMOS Industries }\end{array}$ & 31 & 0.696 \\
\hline Luso F2 & Lusomar & F2 & Closed line since F0 & 30 & 0.720 \\
\hline Emp F0 & Emparn & F0 & Founder animals from TECNARÃO Industry & 08 & 0.699 \\
\hline Aqua F1 (1) & Aquatec & $\mathrm{F} 1$ & $\begin{array}{l}\text { Founder animals from Panama (F0) plus animals from } \\
\text { LUSOMAR and SECOM Industries }\end{array}$ & 20 & 0.699 \\
\hline Aqua F1 (2) & Aquatec & F1 & $\begin{array}{l}\text { Founder animals from Panama (F0) plus animals from } \\
\text { SECOM Industry }\end{array}$ & 20 & 0.705 \\
\hline Aqua F3 & Aquatec & F3 & $\begin{array}{l}\text { Closed line since F1 founded with animals from Panama } \\
\text { (F0) plus animals from LUSOMAR Industry }\end{array}$ & 18 & 0.699 \\
\hline Aqua F4 & Aquatec & F4 & $\begin{array}{l}\text { Animals from F3 plus animals from CAMANOR } \\
\text { Industry }\end{array}$ & 20 & 0.697 \\
\hline Aquama F0 & Aquamaris & F0 & $\begin{array}{l}\text { Nauplius and pos-larvae from AQUALIDER and } \\
\text { COMPAR Industries, respectively }\end{array}$ & 10 & 0.745 \\
\hline Com F0 (1) & Compar & F0 & $\begin{array}{l}\text { Animals from ponds of COMPAR Industry initially } \\
\text { founded with animals from AQUATEC industry }\end{array}$ & 10 & 0.688 \\
\hline Com F0 (2) & Compar & F0 & $\begin{array}{l}\text { Animals from ponds of COMPAR Industry initially } \\
\text { founded with animals from AQUATEC industry }\end{array}$ & 10 & 0.712 \\
\hline Com F0 (3) & Compar & F0 & $\begin{array}{l}\text { Animals from ponds of COMPAR Industry initially } \\
\text { founded with animals from AQUATEC industry }\end{array}$ & 10 & 0.646 \\
\hline Ufsc F0 & UFSC & F0 & Nauplius from MARICULTURA Industry & 10 & 0.712 \\
\hline Ufsc F2 & UFSC & $\mathrm{F} 2$ & $\begin{array}{l}\text { Closed line since F0 found with animals also from } \\
\text { MARICULTURA Industry }\end{array}$ & 10 & 0.733 \\
\hline
\end{tabular}

Information on the origin of the animals of SECOM, EDUARDO LEMOS, TECNARÃO, and CAMANOR Industries was not available. 
manufacturer's instructions. Five decamer primers were used after selection from a panel of 38 tested primers (Table 2). The reactions were carried out in a PT-100 ${ }^{\mathrm{TM}}$ thermal cycler (MJ Research) programmed as follows: 4 minutes of hot start at $94{ }^{\circ} \mathrm{C}$, followed by 35 cycles of 1 minute of denaturation at $92{ }^{\circ} \mathrm{C}, 1.5$ minute of hybridization at $37^{\circ} \mathrm{C}$, and 2 minutes of extension at $72^{\circ} \mathrm{C}$, with a final 3 minutes extension at $72{ }^{\circ} \mathrm{C}$. Fifty nanograms of template DNA and 25 pmoles of primer were used in a final solution volume of $25 \mu \mathrm{L}$, containing $0.4 \mathrm{mM}$ of each dNTP, $2.5 \mu \mathrm{g}$ BSA, $3 \mathrm{mM} \mathrm{MgCl}_{2}, 30 \mathrm{mM} \mathrm{KCl}, 10 \mathrm{mM}$ Tris ( $\mathrm{pH} 8.3$ ), milliQ water, AmpliTaq ${ }^{\mathrm{TM}}$ DNA polymerase, and Stoffel fragment (concentrations not provided by the manufacturer). The amplification products were analyzed in $1.5 \%$ agarose gel with $0.5 \mu \mathrm{g} . \mathrm{mL}^{-1}$ of ethidium bromide ( 3 hours at $100 \mathrm{~V}$ in TBE buffer $1 \mathrm{x}$ ), under ultraviolet light. The Edas 290 (Kodak Digital Science ${ }^{\mathrm{TM}}$ ) system was used for photodocumentation.

\subsection{Statistical analysis}

Fragments of high reproducibility were selected for the statistical analyses, and binary matrixes based on the presence (1) or absence (0) of each fragment were constructed. All statistical tools were based on the analysis of diploid data for dominant molecular data (Yeh et al., 1999). Jaccard's genetic similarity coefficient (Jaccard, 1901) was obtained using the software NTSYS-pc version 1.80 (Rohlf, 1993). Within allele frequencies (Nei, 1987) and genetic distance (Nei, 1972) between the broodstocks were calculated using the software Popgene version 1.31 (Yeh et al., 1999). Allele frequency divergence was tested based on Chi-square analysis $(\mathrm{P}<0.05)$ and homogeneity test between samples. A genetic distance dendrogram based on the UPGMA grouping method was generated (Sneath and Sokal, 1973).

\section{Results}

The five selected primers gave highly reproducible patterns (Figure 1), and a total of 52 polymorphic fragments were scored. The Jaccard's genetic similarity $(\mathrm{Sj})$ ranged from 64.6 to $74.5 \%$ (Table 1).

Allele frequencies were quite variable between samples, presenting significant differences $(\mathrm{P}<0.05)$ for most of the analyzed loci (data not shown). The smallest genetic distance was observed between Luso F0 and Luso F2 (0.0302), while the largest one was identified between Mar NHP and Emp F0 (0.1514) (Table 3). Mar F7 and Mar NHP were both the most divergent lines when comparing to the remaining ones. Six major

Table 2. Decamer primers used in the RAPD reactions.

\begin{tabular}{cc}
\hline Oligonucleotides & Sequence (5' - 3') \\
\hline 2 (GE Healthcare Life Sciences) & GGTGCGGGAA \\
3 (GE Healthcare Life Sciences) & GTTTCGCTCC \\
4 (GE Healthcare Life Sciences) & GTAGACCCGT \\
5 (GE Healthcare Life Sciences) & AAGAGCCCGT \\
6 (GE Healthcare Life Sciences) & AACGCGCAAC \\
\hline
\end{tabular}

branches were revealed in the genetic distance dendrogram (Figure 2). A larger branch (1) joins all broodstocks owned by Aquatec (Aqua F1 (1), Aqua F1 (2), Aqua F3, Aqua F4), and Compar (Com F0 (1), Com F0 (2), Com F0 (3)). A second branch (2) joins Luso F2 and Luso F0. Aquama F0 is alone in branch 3. Ufsc F0 and Ufsc F2 are joined in branch 4, Emp F0 is alone in branch 5, and finally Mar F7 and Mar NHP are joined in branch 6 .

\section{Discussion}

Two main phenomena that are greatly responsible for genetic variation loss in small and isolated breeder populations in captive conditions are the founder effect and inbreeding (Barker, 1994). Breeder selection, the use of captive-reared animals to establish subsequent broodstocks, and the reduced number of breeders (usually 100 dams and 100 sires) commonly used in the hatcheries can favor the decreasing of the genetic diversity levels within a closed broodstock line (e.g. Sbordoni et al., 1986).

Although there is no available information on the genetic variation of wild L. vannamei populations by simi-

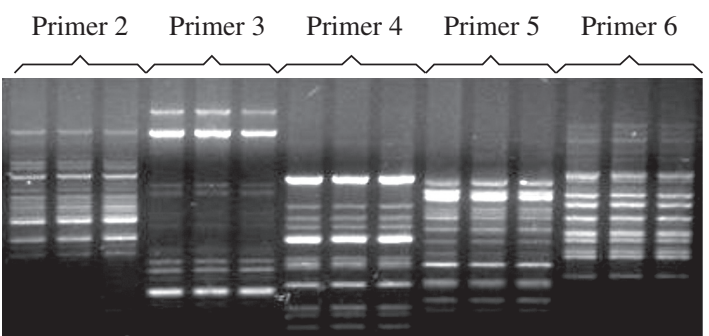

Figure 1. RAPD reproducibility assay in agarose gel. The standardized RAPD reaction made in three distinct times with a single DNA sample using primers $2,3,4,5$, and 6 .

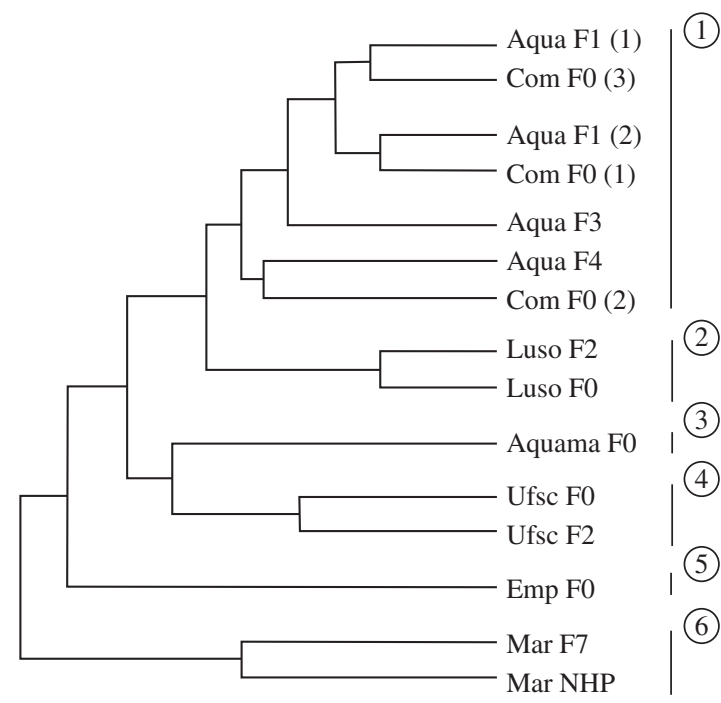

Figure 2. Dendrogram based on the genetic distance for the fifteen studied stocks. Branches are indicated by Arabic numerals (1-6). 


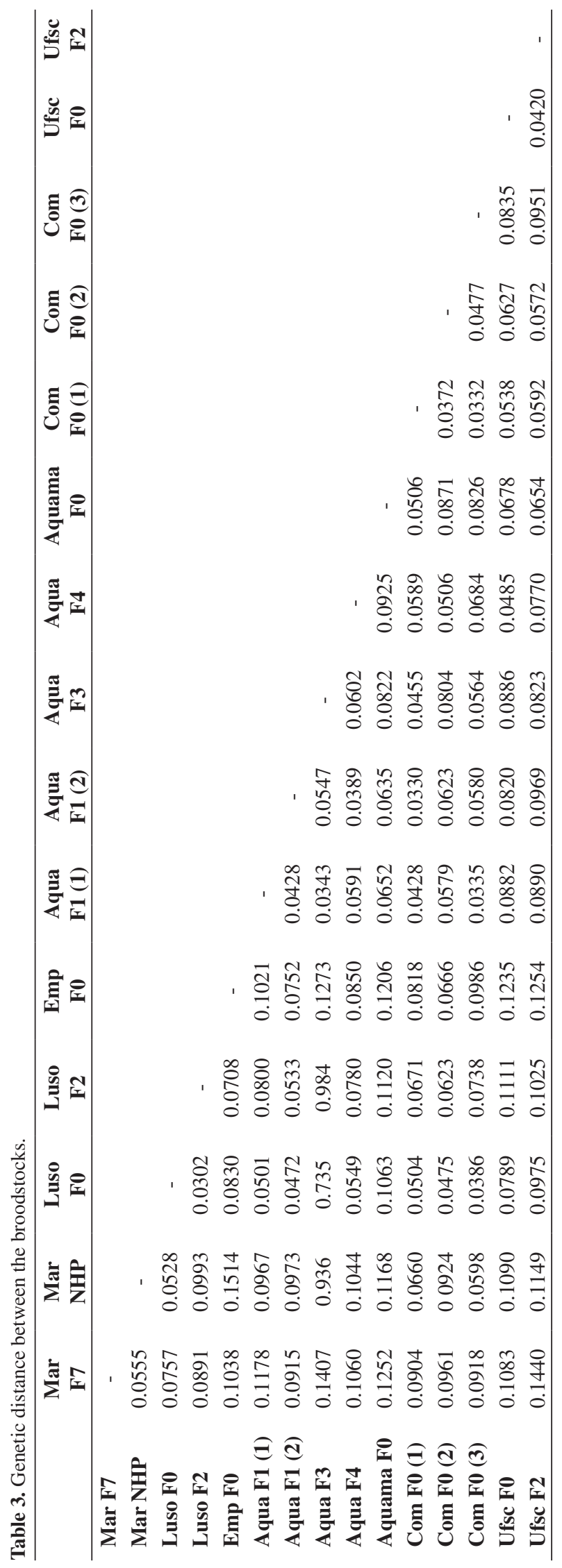


lar RAPD analysis, our results suggest that a significant genetic variation loss occurred in the studied broodstock lines and could be detect in subsequent generations of some closed lines. For instance, $\mathrm{Sj}$ values are slightly increased on Luso F0 to Luso F2 and Ufsc F0 to Ufsc F2. However, a strict correlation between generation time and genetic variation in overall was not found. Some broodstocks (e.g. Aquama F0) at initial generation showed a reduced genetic diversity compared to other older lines (e.g. Mar F7). At least two explanations appear to account for this finding. The lines were founded by gene pools of different origin (Table 1) and the hatcheries have distinct broodstock management, such as different number of breeders in each spawning, usually ranging from 50 to 100 couples. In addition to the genetic drift due to using few breeders, the inbreeding that occurred along the subsequent generations and the selection promoted to distinct captive condition (in special weather and diseases) can also contribute for the significant allele divergence observed among the studied broodstocks.

There is a trend for the clustering among lines owned by a single hatchery, resulting on distinct branches in the genetic distance dendrogram. The exception was observed in the branch \#1 joining broodstocks owned by Aquatec and Compar. It is registered, however, that breeders from Aquatec lines were used to establish both Compar broodstocks studied here, explaining their more strict genetic relationship. The remaining studied broodstocks were separated in different branches following their hatchery origin, reflecting the usual practice to begin a new line in each hatchery with genetic material present in their own living broodstocks. Thus, smaller genetic distance must be expected between broodstocks of a determined hatchery.

Despite of the absence of stock-specific markers, the established genetic relationships provide helpful information to compose new broodstocks. Currently in Brazil, there is a strong technological tendency focused on genetic improvement programs of L. vannamei, with the development of select lines for growth and pathogenfree/resistant individuals (ABCC, 2002). The utilization of genetically unrelated individuals as breeders can increase the levels of genetic variation within new stocks, mitigating possible negative effects caused by genetic drift and/or inbreeding (Thorpe et al., 2000).

Thus, the genetic relationships estimated here among fifteen broodstock lines seem to be an interesting tool for the development of efficient management programs for these animals. In addition, the results suggested that genetic variation monitoring might be very useful to the gene pool conservation currently available for the Brazilian aquaculture industry, mainly if considered the exotic status of this species and the current impossibility of new introductions of wild individuals. Further studies using other nuclear (microsatellites) and mitochondrial molecular markers could contribute to extend the knowledge of the overall genetic variation of the national broodstocks of L. vannamei.
Acknowledgments - This research was supported by Conselho Nacional de Desenvolvimento Científico e Tecnológico (CNPq), and Associação Brasileira de Criadores de Camarão (ABCC). The authors thank the shrimp hatchery industry for the animal samples and useful information about the studied stocks.

\section{References}

ABCC, 2002. O Agronegócio do camarão marinho cultivado. Recife, Associação Brasileira de Criadores de Camarão, 20p.

ALLENDORF, FW. and RYMAN, N., 1987. Genetic management of hatchery stocks. In RYMAN, N. and UTTER, F. (eds.), Population Genetics and Fishery Management. Seattle, University of Washington Press, p. 141-159.

BARKER, JSF., 1994. Animal breeding and conservation genetics. In Loeschcke, V., TOMIUK, J. and JAIN, SK. (eds.). Conservation Genetics. Switzerland, Birkhäuser Verlag Basel, p. 382-395.

FREITAS, PD., CALGARO, MR., DE FRANCISCO, AK. and GALETTI JR., PM., 2001. Um pouco da genética dos nossos plantéis de reprodutores de Litopenaeus vannamei. Rev. ABCC, vol. 3 , no. 1, p. 20-24.

FREITAS, PD. and GALETTI JR., PM., 2002. PCR-based VNTR core sequence analysis for inferring genetic diversity in the shrimp Litopenaeus vannamei. Genet. Mol. Biol., vol. 25, no. 4 , p. 431-344.

JACCARD, P., 1901. Estude comparative de la distribution florale dans une portion des Alpes et des Jura. Bull. Soc. Vaudoise Sci. Nat., vol. 37, p. 547-579.

NEI, M., 1972. Genetic distance between population. Am. Nat., vol. 106 , no. 50 , p. 283-292.

-, 1987. Molecular Evolutionary Genetics. New York, Columbia University Press, 512p.

ROCHA, IP., RODRIGUES, J. and AMORIM, L., 2004. A carcinicultura brasileira em 2003. Recife, ABCC.

ROHLF, FJ., 1993. NTSYS-pc: numerical taxonomy and multivariate analysis system, version 1.80. Exeter software. Setauket, New York.

SAMBROOK, J., FRITSCH, EF. and MANIATIS, T., 1989. Molecular cloning: A Laboratory Manual. $2^{\text {nd }}$ ed. New York, Cold Spring Harbor.

SBORDONI, V., DE MATTHAEIS, M., COBOLLISBORDONI, M., LA ROSA, G. and MATTOCCIA, M., 1986. Bottleneck effects and the depression of genetic variability in hatchery stocks of Penaeus japonicus (Crustacea, Decapoda). Aquaculture, vol. 57, no. 1- 4, p. 239-251.

SNEATH, PA. and SOKAL, RR., 1973. Numerical Taxonomy. San Francisco, Freeman, 573p.

THORPE, JP., SOLÉ-CAVA, AM. and WATTS, PC., 2000. Exploited marine invertebrates: genetics and fisheries. Hydrobiologia, vol. 420, no. 1, p. 165-184.

YEH, F., YANG, R. and BOYLE, T., 1999. Popgene, version 1.31. Microsoft window-based freeware for population genetic analysis. University of Alberta, Edmonton. 
